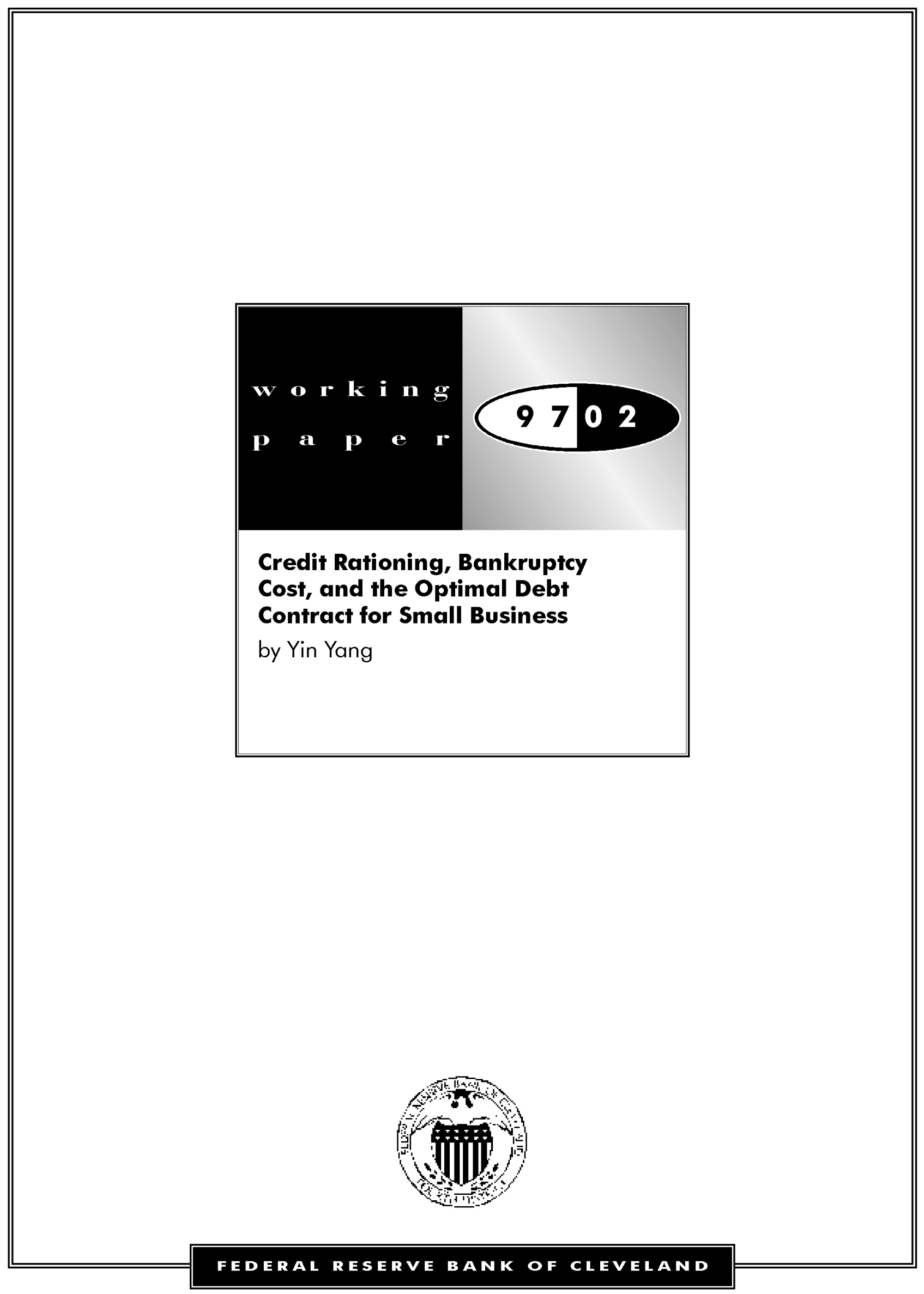


Working Paper 9702

CREDIT RATIONING, BANKRUPTCY COST, AND THE OPTIMAL DEBT CONTRACT FOR SMALL BUSINESS

by Ying Yan

Ying Yan is a visiting economist at the Federal Reserve Bank of Cleveland. This paper is developed from a chapter of her doctoral thesis. The author thanks Michael Balch, Andreas Blume, Jocelyn Evans, Jennifer Reinganum, Calvin Siebert, and Steve Williamson for their helpful comments on earlier versions of this paper. She is grateful for the suggestions and comments of seminar participants at the Federal Reserve Bank of Cleveland, especially those of Joseph Haubrich and Stanley Longhofer.

Working papers of the Federal Reserve Bank of Cleveland are preliminary materials circulated to stimulate discussion and critical comment. The views stated herein are those of the authors and are not necessarily those of the Federal Reserve Bank of Cleveland or of the Board of Governors of the Federal Reserve System.

Federal Reserve Bank of Cleveland working papers are distributed for the purpose of promoting discussion of research in progress. These papers may not have been subject to the formal editorial review accorded official Federal Reserve Bank of Cleveland publications.

Working papers are now available electronically through the Cleveland Fed's home page on the World Wide Web: http://www.clev.frb.org.

March 1997 


\begin{abstract}
This paper examines whether the costly random verification scheme affects the optimal debt contract for small business. It finds, contrary to Townsend (1979) and Williamson (1986, 1987), that the standard debt contract is the optimal debt contract with the costly random verification scheme. Credit rationing, characterized as a loan granted in an amount less than requested, becomes more severe as the bankruptcy cost rises. This result supports the 1994 amendments to the Bankruptcy Code, since it shows that simplifying the bankruptcy procedure for small business reduces credit rationing and therefore enhances lending. (JEL: G2, G3, K2, D8)
\end{abstract}




\title{
Credit Rationing, Bankruptcy Cost, and the Optimal Debt Contract for Small Business
}

\author{
Ying Yan * \\ Visiting Economist
}

\author{
Federal Reserve Bank of Cleveland \\ P.O.Box 6387 \\ Cleveland, $\mathrm{OH} 44101-1387$
}

January 1997

* This paper is developed from one chapter of my doctoral thesis. I would like to thank Michael Balch, Andreas Blume, Jocelyn Evans, Jennifer Reinganum, Calvin Siebert, and Steve Williamson for their helpful comments on early versions of this paper. I am grateful for the suggestions and comments of seminar participants at Federal Reserve Bank of Cleveland, especially those of Joseph Haubrich and Stanley Longhofer. All remaining errors and omissions are mine. Phone: (216) 579-2417 Fax:(216) 579-3050 E-mail: ying.yan@clev.frb.org 
1. Introduction

The most commonly used debt contract is the so-called standard debt contract, which calls for noncontingent repayment of principal plus interest. Whenever this repayment does not occur, bankruptcy proceedings are initiated, and all resources involved are transferred to the lender. The question most often raised is why this simple form of the debt contract is more popular than the complicated contingent debt contract suggested by economic theory. Whether the standard debt contract is optimal and under what conditions it is optimal have been the focus of researchers for many years. This paper tries to justify the standard debt contract's popularity by proving its optimality. ${ }^{1}$

Some papers have analyzed the strategic behavior of borrowers and lenders in an asymmetric information setting during times of financial distress? Haugen and Senbet (1988) argue that once a loan is outstanding, rational creditors will avoid bankruptcy costs by informally restructuring loans. Giammarino (1989) shows that, despite the possibility of costless reorganization, it is rational for lenders to incur bankruptcy costs when there is asymmetric information and the courts have discretion to impose reorganizations. The problem common to these papers is that they ignore how the bankruptcy process affects lenders' initial credit decisions.

Williamson (1986, 1987) views the credit rationing problem from a macroeconomic perspective, where the aggregate supply of funds falls short of the aggregate demand at the market interest rate. In his model, credit rationing stems from

1 See Townsend (1979), Williamson (1986, 1987), and Boyd and Smith (1994).

2 See Haugen and Senbet (1988), Brown (1989), Giammarino (1989), Gertner and Scharfstein (1991), Asquith, Gertner and Scharfstein (1994), and Diamond (1993) to review the financial distress literature. 
an ex-post information asymmetry. 3 Raising the interest rate on loans increases the expected return but also increases the probability of bankruptcy and hence increases the expected bankruptcy cost. Since Williamson $(1986,1987)$ does not allow a bank to restructure the debt, the bank always costly verifies reported incomes when borrowers default. In contrast, the present paper considers both debt restructuring and a more sophisticated monitoring process.

This paper relates credit rationing to bankruptcy and debt restructuring. Previous research does not consider the possibility of a direct link between credit rationing and bankruptcy cost. In contrast to Stiglitz and Weiss (1981) and Williamson $(1986,1987)$, this paper focuses on the type of credit rationing defined by Jaffee and Russell (1976) and Gale and Hellwig (1985), which is characterized as a situation in which the actual loan size granted is smaller than the amount requested. This paper also focuses on whether the costly random verification scheme affects the optimal debt contract for small business. However, it should be noted that the optimal contract derived in this paper is within the framework of debt and is not an optimal contract for inducing truthful reporting. To induce truthful reporting in an asymmetric information setting, as Border and Sobel (1987) and Mookherjee and Png (1989) show, the optimal contract is characterized by a low probability of verification and a large reward for truthful reporting. Both papers mention that this characterization does not apply to debt contracts, since borrowers are not rewarded for truthful reporting.

3 Some credit rationing literature follows Stiglitz and Weiss (1981) in the sense that credit rationing stems from ex-ante information asymmetry. Banks set interest rates below the market clearing level to increase the quality of their loan portfolios. 
The purpose of this paper is to find the debt contract that is optimal for small business with regard to the issues of costly randomized verification, debt restructuring, and credit rationing. The bankruptcy decision is modeled as a strategic choice of the borrower. It is found that, due to asymmetry of information, the bank would not randomize the costly verification even if it could. This is because any randomized verification will induce some borrowers to claim default strategically. The bank considers the bankruptcy cost in its initial credit decision. The results of this paper show that a high bankruptcy cost is more likely to cause credit rationing because the optimal size of the loan decreases as the bankruptcy cost increases.

It is found that the standard debt contract is optimal for small business within the framework of debt, even in the presence of randomized costly verification. This conclusion is quite different from that of Townsend (1979) and Williamson $(1986,1987)$, who conclude that the standard debt contract is optimal only with nonrandom costly verification. Their conclusion follows because, in their model, the borrower is the residual claimant. In the present model, however, when small business borrowers face a local noncompetitive financial market, the lender is the residual claimant. The conclusion in this paper is also the result of assuming a continuous payoff distribution, which is more realistic than the discrete payoff distribution assumed in Townsend (1979). ${ }^{4}$ This paper shows that strict enforcement of the debt collection law will increase banks' expected profits, which in turn facilitates lending. The higher the bankruptcy cost, the higher the inefficiency of the lending market. This conclusion differs from that of Giammarino and Nosal (1994), who state that actions such as exercising judicial discretion, which increase the bankruptcy

4 In Townsend (1979), there are only two possible payoffs. Thus, it is possible to decrease the verification probability slightly from 1 without changing the borrower's incentives to report truthfully. With a continuous payoff distribution, however, any decrease in verification probability from 1 will attract additional solvent borrowers to underreport the payoff, no matter how small that decrease in verification probability is. 
cost, are beneficial because they lower the incidence of inefficient bankruptcy. This paper's result is much stronger than that of Boyd and Smith (1994), who conclude that the standard debt contract is close to optimal because the welfare loss of imposing it is small.

According to a Savings and Community Banker Association survey, an appreciable number of small business loans (about 42\%) fail. Banks' loss exposure from small business loans is very significant. ${ }^{5}$ The results of this paper support the Bankruptcy Reform Act of 1994 by showing that the simplified bankruptcy procedure for small business has great importance in reducing credit rationing and consequently enhancing lending. 6

This paper is organized as follows: Section 2 describes the model and its environment. The resolution of financial distress is discussed in section 3. The issues of optimal debt contract and credit rationing are addressed in section 4. The paper's conclusions and empirical implications are summarized in section 5 .

\section{The Environment}

The borrower in this model has no initial wealth, a simplified feature of small business entrepreneurs in reality. Other features of these entrepreneurs are their low elasticity of demand and low collateral. They usually lack financial expertise and credit histories but must deal with big banks that have a lot of local market power. Thus, the local financial market for those small business entrepreneurs could be approximated as a monopoly market. The banks attempt to set high rates to extract the maximum surplus associated with small business borrowers. The existence of the usury law, which places explicit

5 Creditor losses from business and consumer bankruptcies have risen more than $\$ 12$ billion per year, prompting lenders to cut off the riskiest borrowers (see Marshall [1992]).

6 In April 1994, the Senate proposed amendments to Chapter 11 of the Bankruptcy Code, referred to as Chapter 10, that are intended to provide a less costly process for small business bankruptcies. The intent of Chapter 10 is to speed up the reorganization process in order to reduce legal and accounting fees for small business firms involved in Chapter 11 proceedings and to facilitate the reorganizations. 
maximums on the rate of interest that may be charged for a particular type of loan or borrower, is consistent with the above argument. ${ }^{7}$

In this model, a risk-neutral entrepreneur, who needs to raise external capital to fund an investment project, and a risk-neutral bank are used to capture the agency relationship between a small business borrower and a monopoly lender. The borrower has no initial wealth or tradable collateral. The project payoff is normalized by its highest possible payoff and follows the uniform distribution on the interval $[0,1]$. The distribution of the payoff is common knowledge. However, the realization of the payoff, denoted by $r$, is observable only to the borrower. The bank can observe the realized payoff by incurring a monitoring (bankruptcy) cost.

The contract offered by the bank defines the required payment $\mathrm{R}$, which is the amount of interest plus principal. The required payment $\mathrm{R}$ is also normalized by the highest possible payoff; thus, it is between 0 and 1 . Because of information asymmetry, the bank verifies the cash flow with a positive probability if the borrower claims bankruptcy. This model also allows the bank to credibly commit to a verification policy before the borrower claims bankruptcy. The bank naturally sets the penalty fee (a general function of the difference between the realized payoff and the reported payoff) as large as possible in order to provide the best incentive for truthful reporting. Therefore, if the borrower is found to have underreported his payoff, the bank will take away all the realized payoff.

Kreps and Wilson's (1982) sequential equilibrium concept is used to analyze the model. The borrower's type is identified by his realized payoff, $r$. The borrower's reported payoff, $R^{\prime} \in[0,1]$, might be different from the realized payoff. The probability that the bank verifies the reported payoff when the borrower defaults is denoted by $\mathrm{p}, \mathrm{p} \in[0,1]$, which is determined endogenously. If $\mathrm{p}$ is equal to 1 , the contract becomes a standard debt contact, under which the bank verifies the payoff whenever the borrower defaults. If $\mathrm{p}$ is less than 1 , the bank randomly verifies payoff upon default with probability $\mathrm{p}$.

\footnotetext{
7 See Pettit and McConnell (1991) for the details and effects of the usury law.
} 
It is assumed that the court observes the realized payoff without error, enforces the terms of the debt contract, and does not exercise judicial discretion. ${ }^{8}$ The bankruptcy cost, denoted as L, is determined by legal, administrative, and other professional fees, as well as the opportunity cost associated with bankruptcy procedure. ${ }^{9}$ This cost is initially paid by the bank and then recovered as part of the bank's settlement.

\section{The Resolution of Financial Distress}

It is important to know whether the bank accepts a payment that is less than the full amount and forgives the remaining portion of the debt (hereafter called partial payment). If a partial payment is acceptable, the bankruptcy cost can be avoided and this might benefit both the bank and the borrower, as argued in Haugen and Senbet (1988). Whether partial payment is acceptable or not also depends on the asymmetry between private and public knowledge. In Giammarino (1989), the amount of information available to the public is greater than it is in this model. ${ }^{10}$ Thus, it is not surprising to see that debt restructuring is acceptable in his model but not in this one. In this model, when the borrower claims he has only $\mathrm{R}^{\prime}, \mathrm{R}^{\prime}<\mathrm{R}$, and cannot make the full payment, the lender could choose verify with probability $\mathrm{p}\left(\mathrm{R}^{\prime}\right)$, $\mathrm{p}\left(\mathrm{R}^{\prime}\right) \in[0,1]$. When monitoring is pursued, the lender takes away all the borrower's payoff $\mathrm{r}$ but has to pay

8 The assumed court behavior restricts the cost allocation mechanism, thereby influencing the bank's and the borrower's strategic actions. For example, Giammarino (1989) chooses a cost allocation scheme that eliminates frivolous legal action by the lender. In his paper, an informed court considers the action to be frivolous if the bank refuses to accept a "fair and equitable" offer from the borrower. In this instance, the bank is forced to accept the rejected offer and pay the legal fees. His cost allocation scheme induces the bank to accept settlements that are lower than the face value of the debt. In the model, the bank is not penalized for taking an insolvent borrower to court. Judicial discretion or violations of absolute priority can be estimated as a bankruptcy cost and taken into the bank's consideration when the borrower requests a loan.

9 The opportunity cost of delay associated with bankruptcy can be substantial. Franks and Torous (1993) find that the median resolution periods for renegotiations and bankruptcy are 17 months and 26 months, respectively.

10 There are only two possible states in his model, either solvent or insolvent. However, the present model permits innumerable possible payoffs, each belonging to either the solvent or the insolvent category. 
verification cost L. The borrower gets 0 when the verification is pursued. However, when the lender accepts partial payment, the borrower keeps $r-R^{\prime}, r-R^{\prime} \geq 0$. The following proposition states that the lender will choose verify with certainty, $\mathrm{p}\left(\mathrm{R}^{\prime}\right)=1$, if the debt is not paid in full.

Proposition 1:

Due to the information asymmetry, in equilibrium, the lender chooses to costly verify the borrower's payoff whenever the debt is not paid in full.

The proof (see the appendix) is done by showing that neither a separating nor a pooling and semipooling equilibrium exists when the borrower offers partial payment. It is shown that, on default, the bank cannot have a verification probability less than 1 that induces both solvent and insolvent borrowers to report their payoffs truthfully. Solvent borrowers always have an incentive to mimic insolvent ones when the verification probability is less than 1 . Therefore, the two types of borrowers cannot be distinguished from one another.

All borrowers have an incentive to mimic those with a lower payoff and pool themselves at a lower equilibrium. Therefore, the lowest possible pooling, $[0, p(0)]$ will be the equilibrium result. Any nonzero partial payment will not create a pooling or a semipooling equilibrium. Consequently, banks always initiate bankruptcy proceedings in response to partial payment offers. No partial payment is acceptable without verification in equilibrium. When the borrower defaults, the bank responds by either verifying the payoff through bankruptcy or forgiving the remainder of the debt.

In order to examine how a costly randomized verification scheme affects the form of the debt contract, this model examines two different structures. The first one, where the probability of verification is determined after default, is the signaling structure. The second, where the probability of verification is determined before default, is the screening structure. ${ }^{11}$ For any given verification policy in both structures, there always exists a marginal borrower $r_{0}$ who is indifferent about whether to make the payment or claim

11 This scheme is similar to the mechanism of delegation as commitment in Melumad and Mookherjee (1989). 
default. If the realized payoff is higher than the marginal borrower, $r \mathrm{r}_{0}$, the borrower makes the payment; otherwise, the borrower claims default.

The Signaling Structure

In the signaling structure, the bank does not make any commitment about the verification policy beforehand. Optimally, the verification probability is determined upon the borrower's default. The borrower's decision after observing the payoff--whether to make full payment or claim default--is largely dependent on the cost of litigation. The litigation cost is also the main factor that determines the bank's verification probability. The following lemma reveals the relationship between the marginal borrower and the

cost. 
Lemma:

1. $\mathrm{r}_{0}=\mathrm{R}$ if and only if $\mathrm{L} \leq \mathrm{R} / 2$.

2. $r_{0}>R$ if and only if $L>R / 2$.

Notice that when the marginal borrower's payoff is the same as the required payment, $r_{0}=R$, the debt contract is self-enforcing (truth-telling). The above lemma reveals that a litigation cost that is less than half of the required payment is the sufficient and necessary condition for the debt contract to be selfenforcing. This is because the realized payoff follows a uniform distribution. When the marginal borrower's payoff is $r_{0}$, the lender's expected benefit from verification is $r_{0} / 2$. As long as the expected benefit exceeds the expected cost, that is, $\mathrm{L} R / 2$, the bank verifies the payoff upon the borrower's default. The bank's expected payoff will decrease if its verification probability is less than 1 in this range. Consequently, solvent borrowers never attempt to claim bankruptcy. When $L>R / 2$, however, the bank does not benefit, on average, from verifying payoff with certainty upon default. Hence, verification probability is less than 1 . Some solvent borrowers take advantage of this by claiming default and get away with it.

Without loss of generality, the litigation cost is an exogenous variable in this model. ${ }^{12}$ The equilibrium marginal borrower $\mathrm{r}_{0}{ }^{*}$ and the equilibrium verification probability $\mathrm{p}^{*}$ are determined endogenously. The borrower's payoff is taken away whenever verification is pursued. The marginal borrower is indifferent about whether to make the full payment or default. The following proposition shows that verification probabilities are inversely related to the bankruptcy cost. The higher the marginal borrower's payoff, the more solvent borrowers claim default.

Proposition 2:

The equilibrium solution in the signaling model is as follows:

12 The litigation cost usually rises with total assets when the firm is big. However, the cost of bankruptcy proceedings for a small firm generally does not rise much with total assets. Thus, the exogenous litigation cost does not seems to be an imposition for small business in this model. 
1. If $\mathrm{L} \leq \mathrm{R} / 2$, then $\mathrm{r}_{0}{ }^{*}=\mathrm{R}$ and $\mathrm{p}^{*}=1$.

2. If $1 / 2 \geq \mathrm{L}>\mathrm{R} / 2$, then $\mathrm{r}_{0}{ }^{*}=2 \mathrm{~L}$ and $\mathrm{p}^{*}=\mathrm{R} / 2 \mathrm{~L}$.

3. If $L>1 / 2$, the bank does not lend and the market fails.

[Proof]: With the lemma, it is easy to understand that, in equilibrium, if the litigation cost is less than half of the required payment, $\mathrm{L} R / 2$, the bank verifies payoff with certainty upon default and the borrower makes the payment whenever he can, that is $\mathrm{r}_{0}{ }^{*}=\mathrm{R}$ and $\mathrm{p}^{*}=1$. However, if the litigation cost is larger than half of the required payment, $\mathrm{L}>\mathrm{R} / 2$, the bank faces the following problem:

$$
\operatorname{Max}_{\mathrm{p}}\left\{\left(1-\mathrm{r}_{0}\right) \mathrm{R}+\mathrm{r}_{0} \mathrm{p} \times\left(\mathrm{r}_{0} / 2-\mathrm{L}\right)\right\} .
$$

The first term is the expected payoff from the borrower who makes full payment. The second term is the expected payoff from the borrower who claims default and is verified with probability $\mathrm{p}$. The reaction function of the bank, which is the first-order condition of equation (1), is $r_{0}=2 \mathrm{~L}$. The borrower's reaction function, which is characterized by the marginal borrower's indifference to making the payment versus defaulting, is $r_{0}=R / p$. With both parties' reaction functions, a unique equilibrium is reached at $r_{0}{ }^{*}=2 \mathrm{~L}$ and $\mathrm{p}^{*}=\mathrm{R} / 2 \mathrm{~L}$. Notice that $\mathrm{p}^{*}$ cannot be greater than 1 , thus $\mathrm{L} \mathrm{R} / 2$. It is obvious that more solvent borrowers claim default when bankruptcy cost rises. With $\mathrm{r}_{0}{ }^{*}=2 \mathrm{~L}$ and $\mathrm{p}^{*}=\mathrm{R} / 2 \mathrm{~L}$, equation (1) is simplified to $\mathrm{R}(1-2 \mathrm{~L})$. When $\mathrm{L}>1 / 2$, the expected payoff becomes negative. The bank does not have any incentive to lend. Therefore, the market fails.

Q.E. D.

The equilibrium solution of the problem is determined by the size of the litigation cost. The standard debt contract occurs as the equilibrium strategy and it is self-enforcing when the litigation cost is less than half of the required payment. The randomized verification occurs in equilibrium when the litigation cost is higher than half of the required payment. However, if the litigation cost is so high that the bank's expected payoff turns negative, then the bank stops lending and the market fails.

The Screening Structure 
In the screening structure, the bank commits to a verification policy when the debt contract is signed. Optimally, the verification probability upon default, q, is chosen ex ante. Thus, the bank has more power to affect the borrower's decision in the screening structure than it does in the signaling structure. 13 The bank's advantage from moving first plays an important role here, since the bank takes the borrower's reaction function into consideration when it commits to the verification policy. The equilibrium behavior is as follows:

13 In game theory, this is called first-mover advantage. 


\section{Proposition 3:}

In the screening structure, the standard debt contract occurs as the equilibrium strategy and is selfenforcing when the litigation cost is low, $\mathrm{q}^{*}=1$ and $\mathrm{r}_{0}{ }^{*}=\mathrm{R}$ if $\mathrm{L} 1-\mathrm{R} / 2$. The bank stops lending and the market fails when the litigation cost is high, a condition which occurs when $\mathrm{L}>1-\mathrm{R} / 2$.

[Proof]: The bank faces the following problem:

$$
\begin{aligned}
& \operatorname{Max}_{\mathrm{q}}\left\{\left(1-\mathrm{r}_{0}\right) \mathrm{R}+\mathrm{r}_{0} \mathrm{q} \times\left(\mathrm{r}_{0} / 2-\mathrm{L}\right)\right\} \\
& \text { s.t. } \mathrm{r}_{0}=\mathrm{R} / \mathrm{q} .
\end{aligned}
$$

The first term of the objective function is the expected payoff from the borrower who makes full payment. The second term is the expected payoff from the borrower who defaults and is verified with probability q. However, notice that verification with probability $\mathrm{q}$ takes the borrower's reaction function into consideration. Thus, the borrower's reaction function $r_{0}=R / q$ needs to be taken into the bank's objective function to solve for $\mathrm{q}$. The objective function, after being simplified to $\mathrm{R}[1-\mathrm{L}-\mathrm{R} /(2 \mathrm{q})]$, is maximized at

$q^{*}=1$. Consequently, the equilibrium marginal borrower $r_{0}{ }^{*}$ equals the required payment $\mathrm{R}$ in this case.

When the litigation cost is higher than 1-R/2, the expected payoff of the bank $R[1-L-R /(2 q)]$ turns negative, with $\mathrm{q}^{*}=1$ and $\mathrm{r}_{0}{ }^{*}=\mathrm{R}$. Therefore, the bank stops lending and the market fails.

Q.E.D.

The main feature of the standard debt contract is that the bank verifies whenever the borrower defaults. When the litigation cost is in the low range, $\mathrm{L} 1-\mathrm{R} / 2$, the bank's commitment $\mathrm{q}^{*}=1$ is credible and effectively deters the borrower from falsely announcing bankruptcy. However, when the litigation cost is beyond that range, this commitment is not credible any more; consequently, the market fails.

The next section makes an overall comparison of the two structures to seek the optimal form of debt contract.

\section{The Optimal Debt Contract and Credit Rationing}

The optimal contract has been the center of financial contracting. However, the standard debt contract has never before been identified as the optimal contract within the framework of costly random 
verification, because of the ways the models were set up. This section uses a nonconventional approach to show that the standard debt contract is the optimal debt contract with the costly random verifications for small business borrowers.

First, the two structures are compared in the expected payoffs in equilibrium. Second, the optimal required payment is determined for the dominating strategy. Third, the optimality of the standard debt contract is proved with random costly verification. Finally, the credit rationing issue is addressed through the direct relationship between the bankruptcy cost and the optimal required payment.

Proposition 4: The screening structure weakly dominates the signaling structure.

[Proof]: The proof is completed by comparing the equilibrium expected payoff in the three different litigation cost ranges.

When $\mathrm{L} R / 2$, the equilibrium result is $\mathrm{r}_{0}{ }^{*}=\mathrm{R}$ and $\mathrm{p}^{*}=1$ in the signaling structure. Thus, the expected payoff for the bank is $\mathrm{R}[1-\mathrm{R} / 2-\mathrm{L}]$. The screening structure, with equilibrium $\mathrm{r}_{0}{ }^{*}=\mathrm{R}$ and $\mathrm{q}^{*}=1$, has the same expected payoff in this range. This is because the lowest marginal borrower's payoff is the required payment R. Since the signaling structure already achieves the best result, the screening structure cannot do better.

When $1 / 2 \mathrm{~L}>\mathrm{R} / 2$, the equilibrium result is $\mathrm{r}_{0}{ }^{*}=2 \mathrm{~L}$ and $\mathrm{p}^{*}=\mathrm{R} / 2 \mathrm{~L}$ in the signaling structure. The corresponding expected payoff for the bank is $\mathrm{R}[1-2 \mathrm{~L}]$. In contrast, the equilibrium result is $\mathrm{r}_{0}{ }^{*}=\mathrm{R}$ and $\mathrm{q}^{*}=1$ in the screening structure. The corresponding expected payoff for the bank is $R[1-R / 2-L]$. Because $\mathrm{L}>\mathrm{R} / 2$, the expected payoff from the screening structure is greater than that from the signaling structure.

The market fails in the signaling structure when $\mathrm{L}>1 / 2$. The market fails in the screening structure when $\mathrm{L} 1-\mathrm{R} / 2$. Since $\mathrm{R}<1$, therefore, $1-\mathrm{R} / 2>1 / 2$. When the litigation cost is high, the signaling structure fails before the screening structure does. Therefore, the screening structure dominates the signaling structure.

Q. E. D. 
The above proposition shows that the screening structure provides higher expected payoff to the bank. Therefore, the bank will choose to commit to a verification policy before bankruptcy occurs. Proposition 3 shows that if the bank commits to a verification policy before bankruptcy, it will commit to the policy of verifying payoff with certainty upon default. The above results lead to the following proposition:

Proposition 5: The standard debt contract is the optimal debt contract for small business with costly random verification.

[Proof]: The feature of the standard debt contract is that the lender verifies whenever the borrower defaults.

Proposition 4 shows that the bank prefers committing to a verification policy beforehand instead of afterward with costly random verification. Proposition 3 shows that the equilibrium strategy in committing to a verification policy beforehand is that the bank verifies with certainty upon default. This is also a feature of the standard debt contract. Therefore, with propositions 3 and 4 , it is easy to see that the standard debt contract is the optimal contract for small business with costly random verification.

Q. E. D.

The statement just made, which is the primary result of this paper, strongly justifies the popularity of the standard debt contract. This result applies to small business borrowers because the local financial markets they face are usually noncompetitive. For a competitive financial market, the standard debt contract is optimal only with nonrandom costly verification, as shown in Townsend (1979) and Williamson (1986, 1987). Our result is perfectly compatible with theirs and it serves as a useful supplement for understanding the standard debt contract.

Our approach to credit rationing is also nonconventional. When required payment is modeled explicitly, loan size and interest rate are modeled implicitly. In this model, credit rationing occurs implicitly instead of being modeled explicitly. The following proposition reveals the direct relationship between the optimal required payment and the size of the litigation cost. 
Proposition 6: The optimal required payment is negatively related to the size of the litigation cost. The relationship between them is $\mathrm{R}^{*}=(1-\mathrm{L})$.

[Proof]: With propositions 3 and 4, the bank maximizes the expected payoff as follows:

$$
\begin{array}{ll}
\operatorname{Max}_{\mathrm{R}} & \left\{\left(1-\mathrm{r}_{0}{ }^{*}\right) \mathrm{R}+\mathrm{r}_{0}{ }^{*} \mathrm{q}^{*} \times\left(\mathrm{r}_{0}{ }^{*} / 2-\mathrm{L}\right)\right\} \\
\text { s.t. } & \mathrm{r}_{0}{ }^{*}=\mathrm{R} \text { and } \mathrm{q}^{*}=1 .
\end{array}
$$

The expected function is simplified to $\mathrm{R}(1-\mathrm{R} / 2-\mathrm{L})$. The uniqueness of the maximization is proved by showing that the second-order condition with respect to $\mathrm{R}$ is negative. The first-order condition gives maximization when $\mathrm{R}^{*}=1-\mathrm{L}$.

Q.E. D.

The negative relationship between litigation cost and the optimal required payment has considerable importance for credit rationing. When the borrower requests a loan in which the required payment is lower than the optimal required payment $1-\mathrm{L}$, no credit rationing occurs and the bank earns positive profit $\mathrm{R}(1-\mathrm{R} / 2-\mathrm{L})$. When the borrower requests a loan in which the required payment is higher than the optimal required payment, the bank will ration credit to make the required payment equal to $1-\mathrm{L}$, in order to maximize the expected profit. It is important to observe that the size of the required payment decreases as the bankruptcy cost rises. This means that credit rationing is more likely to occur and is probably more severe when the bankruptcy cost is high. 


\section{Conclusions and Empirical Implications}

This paper examines whether the costly random verification schemes affect the optimal debt contract for small business. It finds that, for small business, the standard debt contract is the optimal debt contract with the costly random verification scheme. This result justifies the popularity of the standard debt contract more strongly than previous findings on this issue. ${ }^{14}$ Although Townsend (1979) and Williamson $(1986,1987)$ conclude that the standard debt contract is optimal only with nonrandom costly verification, the results of this paper do not conflict with theirs. This is because their results are developed under the competitive financial market condition, while ours are derived under the noncompetitive financial market condition which small business borrowers face.

This paper relates credit rationing to bankruptcy and debt restructuring in a direct linkage which is not found in earlier contributions. The key point here is that banks rationally take bankruptcy cost into account when they make loans. High bankruptcy cost prevents banks from making big loans to small business borrowers because of the high possibility of loan losses. Credit rationing occurs as a natural means of alleviating loan losses. Because banks' losses on small business loans are highly significant, credit rationing is very serious for small business. ${ }^{15}$ Since credit rationing is negatively related to bankruptcy cost, our results strongly support the Bankruptcy Reform Act of 1994, which simplifies the bankruptcy procedure for small business. According to Holly (1994), 80\% of U.S. firms are classified as small businesses. Hence, the Bankruptcy Reform Act of 1994, by reducing credit rationing to small business, should have significant positive repercussions on the economy.

The result that the standard debt contract is the optimal contract for small business could be verified empirically by comparing violations of the absolute priority rule in small firms' bankruptcies versus big firms' bankruptcies. This project is currently being pursued in another paper. The negative relationship between bankruptcy cost and credit rationing can also be tested empirically. To my knowledge,

14 See Boyd and Smith (1994).

15 See Buck, Friedman, and Dunkelberg (1991). 
existing studies that test for credit rationing do not consider the relevance of bankruptcy cost or differentiate between large and small firms. ${ }^{16}$ Therefore, further empirical results in this area should be very interesting.

16 See Aghion and Bolton (1991), Aghion, Hart, and Moore (1992), Berkovitch, Israel, and Zender (1993), and Berger and Udell (1992). 


\section{APPENDIX}

\section{PROOF OF PROPOSITION 1}

Suppose there exists a separating equilibrium $\left[\mathrm{R}^{\prime}, \mathrm{p}\left(\mathrm{R}^{\prime}\right)\right]$ for $\mathrm{R}^{\prime}<\mathrm{R}$. When the borrower reports that the realized payoff is $\mathrm{R}^{\prime}$, he gives the lender $\mathrm{R}^{\prime}$. The lender verifies with probability $p\left(\mathrm{R}^{\prime}\right)$. It is assumed that the borrower with realized payoff $\mathrm{r}=\mathrm{R}^{\prime}+\mathrm{c}$ (where $\mathrm{c}$ is an arbitrary positive number), reports $\mathrm{R}^{\prime}$ and the bank responds with different $\mathrm{p}\left(\mathrm{R}^{\prime}\right)$ to maximize the expected payoff. ${ }^{17}$

If a separating equilibrium exists, the bank faces the following problem:

$$
\operatorname{Max}_{p\left(R^{\prime}\right)}\left[1-p\left(R^{\prime}\right)\right]^{*} R^{\prime}+p\left(R^{\prime}\right) *\left(R^{\prime}+c-L\right) .
$$

The first term is the expected payoff when the bank does not verify the reported payoff. The second term is the expected payoff when the bank verifies and pays the bankruptcy cost. This expected payoff could be simplified to $\mathrm{R}^{\prime}-\mathrm{p}\left(\mathrm{R}^{\prime}\right)^{*}(\mathrm{~L}-\mathrm{c})$. When $\mathrm{c}<\mathrm{L}$, the optimal probability for the bank is $\mathrm{p}\left(\mathrm{R}^{\prime}\right)^{*}=0$. However, with verification probability 0 , the borrower has no incentive to separate himself from the lower types of borrowers. Therefore, the separating equilibrium breaks down. When $\mathrm{c}>\mathrm{L}$, the optimal probability of the bank's maximizing the expected payoff is $\mathrm{p}\left(\mathrm{R}^{\prime}\right)^{*}=1$. However, with verification probability 1 , all the insolvent borrowers will lose all the payoff. The separating equilibrium can be broken down easily, since borrowers have no incentive to separate themselves.

Suppose there exist two pooling equilibria -- $\left[R^{\prime}, p\left(R^{\prime}\right)\right]$ and $\left[R^{\prime \prime}, p\left(R^{\prime \prime}\right)\right]--$ where $R^{\prime}, R^{\prime \prime} \quad 0, R^{\prime \prime}<R^{\prime}$ and $p\left(R^{\prime \prime}\right)>p\left(R^{\prime}\right)$. All the borrowers with realized payoff higher than $R^{\prime}$ should pool at $R^{\prime}$. All the borrowers with realized payoff between R' and R" should pool at R". However, the following shows that this is not true: The expected payoff for a borrower with $r=R^{\prime}+\quad$ pooling at $R^{\prime}$ is $\left[1-p\left(R^{\prime}\right)\right]\left[r-R^{\prime}\right]=[1-$ $\left.p\left(R^{\prime}\right)\right]^{*}$. The expected payoff if this borrower pools at $R^{\prime \prime}$ is $\left[1-p\left(R^{\prime \prime}\right)\right]\left[r-R^{\prime \prime}\right]=\left[1-p\left(R^{\prime \prime}\right)\right]\left[R^{\prime}+\quad-R^{\prime \prime}\right]$. If he

17 It is necessary to keepc constant across all types of borrowers to make them separate themselves from one another. 
pools at $\mathrm{R}^{\prime}$, then it must be $\left[1-\mathrm{p}\left(\mathrm{R}^{\prime}\right)\right]^{*}>\left[1-\mathrm{p}\left(\mathrm{R}^{\prime \prime}\right)\right]\left[\mathrm{R}^{\prime}+\quad-\mathrm{R}^{\prime \prime}\right]$. That is, $\left[\mathrm{p}\left(\mathrm{R}^{\prime \prime}\right)-\mathrm{p}\left(\mathrm{R}^{\prime}\right)\right]^{*}>\left[1-\mathrm{p}\left(\mathrm{R}^{\prime \prime}\right)\right]\left[\mathrm{R}^{\prime}-\right.$ R"]. However, when $\rightarrow 0$, the above inequality will be violated. Therefore, this borrower will mimic other low payoff borrowers by pooling at R" instead of R'. Thus, the pooling equilibrium always breaks down until it is zero. 


\section{REFERENCES}

Aghion, P. and P. Bolton, 1991, An Incomplete Contracts Approach to Financial Contracting, Review of Economic Studies 59, 473494.

Aghion, P., O. Hart and J. Moore, 1992, The Economics of Bankruptcy Reform, Journal of Law. Economics and Organization 8, 523-546.

Aivazian, V.A. and J. L. Callen, 1983, Reorganization in Bankruptcy and the Issue of Strategic Risk, Journal of Banking and Finance 7, 119-183.

Asquith, P., R. Gertner and D. Scharfstein, 1994, Anatomy of Financial Distress: An Examination of Junk Bond Issuers, Quarterly Journal of Economics 109, 625658.

Berger, A. and G. Udell, 1992, Some Evidence on the Empirical Significance of Credit Rationing, Journal of Political Economy 100, 1047-1077.

Berkovitch, E., R. Israel and J. Zender, 1993, The Design of Bankruptcy Law: A Case for Management Bias in Bankruptcy Reorganizations, Working Paper (University of Michigan).

Besanko, D. and A. Thakor, 1987, Collateral and Rationing; Sorting Equilibria in Monopolistic and Competitive Credit Markets, International Economic Review 28, 671-689.

Border, K. and J. Sobel, 1987, A Theory of Auditing and Plunder, Review of Economic Studies, 54, 525-540.

Boyd, J. H. and Bruce D. Smith, 1994, How Good Are Standard Debt Contracts? Stochastic versus Nonstochastic Monitoring in a Costly State Verification Environment, Journal of Business 67, 539-561.

Brown, D., 1989, Claimholder Incentive Conflicts in Reorganization: The Role of Bankruptcy Law, The Review of Financial Studies 2, 109-123.

Brown, D., C. James and R. Mooradian, 1993, The Information Content of Distressed Restructuring Involving Public and Private Debt Claims, Journal of Financial Economics 33, 93-118.

Buck, A. J., J. Friedman and W. C. Dunkelberg, 1991, Risk and Return in Small Business Lending: The Case of Commercial Banks, Advances in Small Business Finance (ed. R. Yazdipour), Boston, Kluwer Academic Publishers, 121-137.

Chan, Y. and G. Kanatas, 1985, Asymmetric Valuation and the Role of Collateral in Loan Agreements, Journal of Money, Credit and Banking 17, 84-95.

Chatterjee, S., U. Dhillon and G. Ramirez, 1994, Resolution of Financial Distress, Debt Restructuring via Chapter 11 Reorganizations, Prepackaged Bankruptcies, and Public Workouts, Working Paper (Fordham University). 
Diamond, D., 1984, Financial Intermediation and Delegated Monitoring, Review of Economic Studies 51, 393-414.

, 1993, Seniority and the Maturity of Debt Contracts, Journal of Financial Economics 33, 341-368.

Dye, R., 1986, Optimal Monitoring Policies in Agencies, Rand Journal of Economics $17,339-350$.

Franks, J. and W. Torous, 1989, An Empirical Investigation of U.S. Firms in Chapter 11 Reorganization, Journal of Finance 44, 747-767.

and 1993, A Comparison of Financial Recontracting in Distressed Exchanges and Chapter 11 Reorganizations, Working Paper (London Business School).

Gale, D. and M. Hellwig, 1985, Incentive-Compatible Debt Contracts: The One-Period Problem, Review of Economic Studies, 52, 647-64.

Gertner, R. and D. Scharfstein, 1991, A Theory of Workouts and the Effects of Reorganization Law, Journal of Finance 46, 1189-1222.

Giammarino, R., 1989, The Resolution of Financial Distress, Review of Financial Studies 2, 25-47.

Giammarino, R. and E. Nosal, 1994, The Efficiency of Judicial Discretion in Bankruptcy Law, Working Paper (University of British Columbia).

Gilson, S., K. John and L. Lang, 1990, Trouble Debt Restructuring: An Empirical Study of Private Reorganization of Firms in Default, Journal of Financial Economics 27, 315-353.

Haugen, R. and L. Senbet, 1988, Bankruptcy and Agency Costs: Their Significance to the Theory of Optimal Capital Structure, Journal of Financial and Quantitative Analysis 23, 27-38.

Hillier, B. and M. Ibrahimo, 1993, Asymmetric Information and Models of Credit Rationing, Bulletin of Economic Research 45, 271-304.

Holly, S., 1994, Small Businesses Rate High with Credit Scorecards, Bank Systems and Technology 31, 28-30.

Jaffee, D., and T. Russell, 1976, Imperfect Information, Uncertainty, and Credit Rationing, Quarterly Journal of Economics 90, 651-666.

Kreps, D., and R. Wilson, 1982, Sequential Equilibria, Econometrics 50, 863-894.

Marshall, J., 1992, Lenders Take Aim at Bankruptcy Code, United States Bankers, January, 16-19. 
Melumad, N., and D. Mookherjee, 1989, Delegation As Commitment: The Case of Income Tax Audits, Rand Journal of Economics 20, 139-163.

Mookherjee, D. and I. Png, 1989, Optimal Auditing, Insurance, and Redistribution, Quarterly Journal of Economics 104, 399415.

Pettit, R. and J. McConnell, 1991, The Impact of Usury Laws on the Effectiveness and Efficiency of the Operation of Small Business, Small Business Finance (ed. P. Horvitz and R. Pettit), Boston, JAI Press Inc.

Reinganum, J. and L. Wilde, 1986, Settlement, Litigation, and Allocation of Litigation Costs, Rand Journal of Economics 17, 557-566.

Riley, J., 1987, Credit Rationing, A Further Remark, American Economic Review 77, 224-227.

Stiglitz, J. and A. Weiss, 1981, Credit Rationing in Markets with Imperfect Information, American Economic Review 71, 393-410.

and _ 1987, Credit Rationing with Many Borrowers, American Economic Review 77, 228-231.

Townsend, R., 1979, Optimal Contracts and Competitive Markets with Costly State Verification, Journal of Economic Theory 21, 1-29.

, 1988, Information Constrained Insurance: The Revelation Principle Extended, Journal of Monetary Economics 21, 411-450.

Warner, J., 1977, Bankruptcy Costs: Some New Evidence, Journal of Finance 32, 239276.

Webb, D., 1987, The Importance of Incomplete Information in Explaining the Existence of Costly Bankruptcy, Economica 54, 279-288.

Williamson, S., 1986, Costly Monitoring, Financial Intermediation, and Equilibrium Credit Rationing, Journal of Monetary Economics 18, 159-179.

, 1987, Costly Monitoring, Loan Contracts, and Equilibrium Credit Rationing, Quarterly Journal of Economics 102, 135-145. 